\title{
PENGELOLAAN DAN PENDAYAGUNAAN TANAH WAKAF DI PONDOK PESANTREN ASSALAFIYAH LUWUNGRAGI BREBES
}

\author{
Edy Setyawan, Asep Saepullah, Fitri Fahrunnisa \\ Fakultas Syariah dan Ekonomi Islam \\ Institut Agama Islam Negeri Syekh Nurjati Cirebon \\ email :fitrifahrunnisa09@gmail.com
}

\begin{abstract}
ABSTRAK
Pelaksanaan pengelolaan wakaf saat ini dilakukan dengan inovasi baru oleh nadzir untuk lebih bermanfaat dan produktif. Salah satu pengelolaan wakaf yang demikian dilakukan oleh yayasan Pondok Pesantren Assalafiyah di Desa Luwungragi. Nadzir wakafnya mencoba mengembangkan tanah wakaf sebagai sarana untuk mengembangkan pondok pesantrennya untuk mencapai kesejahteraan pondok pesantren. Metode yang digunakan dalam penelitian ini adalah kualitatif dimana sifat penelitiannya deskriptif analisis. Teknik pengumpulan data dilakukan dengan cara observasi, wawancara (interview), dan studi dokumentasi. Dari hasil penelitiannya pengelolaan wakaf di Pondok Pesantren Assalafiyah menurut syariat Islam sudah sesuai dimana pada prinsip syariat harta wakaf tidak boleh dijual, diwariskan dan dihibahkan. Prinsip tersebut telah dilakukan pada Pondok Pesantren Assalafiyah dan dikelola dengan baik. Pendayagunaan tanah wakafnya sudah dimanfaatkan dengan baik sesuai dengan ikrar wakaf dimana tanah wakafnya didayagunakan untuk sawah sehingga lebih produktif dan berkontribusi maksimal untuk pengembangan pesantren.
\end{abstract}

Kata Kunci: Pengelolaan, Pendayagunaan Tanah Wakaf, Produktif, dan Assalafiyah

\begin{abstract}
The implementation of "wakaf" management nowdays involves new innovation by "nadzir" to make it more useful and productive. One of the management of "wakaf" is applied by Assalafiyah Islamic Boarding School in Luwungragi Village. The "nadzir" of "wakaf" attempts to improve "tanah wakaf" as medium to improve the quality of the Islamic Boarding School to achieve its prosperity. The method involved in this research is qualitative concerning on descriptive analysis. The technique to gather data involves observation, interview, and documentation. The result of the research shows that the management of "wakaf" at Assalafiyah Islamic Boarding School according to the principle of "Syariat wakaf" that "harta wakaf" is not allowed to be sold, to be inherited, and to be given. The principle has implemented at Assalafiyah Islamic Boarding School and it is managed well. The utilization of "tanah wakaf" is applied well and it is appropriate to "ikrar wakaf" between "wakaf" and "nadzir" that is "tanah wakaf" is used to be rice field so it is more productive and contributes maximally to the improvement of the Islamic Boarding School.
\end{abstract}

Keywords: The management, The utilization of "tanah wakaf", Productive, "Assalafiyah". 


\section{PENDAHULUAN}

Salah satu dari bentuk ibadah dengan tujuan untuk mendekatkan diri kepada Allah SWT yang berkaitan dengan harta benda adalah wakaf. Amalanamalannya sangat besar bagi kehidupan sosial ekonomi, kebudayaan, dan keagamaan. Oleh karena itu, Islam meletakkan amalan wakaf sebagai salah satu macam ibadah yang amat digembirakan ${ }^{1}$ dan diistimewakan.

Perkembangan wakaf dari masa ke masa ini tidak didukung oleh Peraturan formal yang mengaturnya, praktik perwakafan selama itu hanya berpedoman kepada kitab-kitab fiqh tradisional yang disusun beberapa abad yang lalu. Wakaf adalah perbuatan hukum wakif untuk memisahkan dan/atau menyerahkan sebagian harta benda miliknya untuk dimanfaatkan selamanya atau untuk jangka waktu tertentu sesuai dengan kepentingannya guna keperluan ibadah dan/atau kesejahteraan umum menurut syariah. $^{2}$ Dalam pemanfaatannya, agar dapat mencapai tujuan dan fungsi wakaf, harta benda wakaf dapat diperuntukkan sebagai: (1) sarana dan kegiatan ibadah, (2) sarana dan kegiatan pendidikan serta kesehatan, (3) bantuan kepada fakir miskin, anak terlantar, yatim piatu, beasiswa, (4) kemajuan dan peningkatan ekonomi umat dan/atau, (5) kemajuan kesejahteraan umum lainnya yang tidak bertentangan dengan syariah dan peraturan perundang-undangan. ${ }^{3}$

Pengelolaan dan pengembangan harta benda wakaf itu tidak sembarang

1 Ahmad Azhar Basyir, Hukum Islam tentang Wakaf, Ijarah, dan Syirkah (Bandung: PT Al-Ma'arif, 1987), 7.

2 Undang-undang No. 41 tahun 2004

Tentang Wakaf Pasal 1 ayat 1 .

3 Undang-undang No. 41 tahun 2004 Tentang Wakaf Pasal 22. orang yang melakukannya. Wakaf dikelola dan dikembangkan oleh seorang nadzir dan harus sesuai dengan prinsip syariah yang dilakukan secara produktif. Dalam sejarah Indonesia, wakaf telah dikenal dan dilaksanakan oleh umat Islam sejak agama Islam masuk di Indonesia. Sebagai suatu lembaga Islam, wakaf telah menjadi salah satu penunjang perkembangan masyarakat Islam. Di Brebes khususnya, wakaf sangat diperhatikan mengingat fungsi wakaf itu sangat penting. Pada daerah Brebes pelaksanaan dari praktik pengelolaan wakaf masih berdasarkan syari'at Islam, walaupun tidak keseluruhan namun sedikitnya di daerah Brebes masih bisa di rasakan eksistensi dari pelaksanaan yang berdasarkan syari'at Islam ini dikarenakan tradisi di daerah Brebes masih kental sehingga apa yang menjadi permasalahan di desa selalu di selesaikan melalui jalan yang sesuai dengan syari'at Islam. Seperti halnya permasalahan wakaf yang terjadi di salah satu pondok pesantren Brebes yakni Pondok Pesantren Assalafiyah di Desa Luwungragi Kecamatan Bulakamba Kabupaten Brebes.

Dikarenakan semakin banyaknya peminat orang-orang disekitar desa Luwungragi yang ingin menuntut ilmu melalui pondok pesantren maka di dirikanlah Pondok Pesantren Assalafiyah dengan maksud agar warga masyarakat sekitar bisa mencari ilmu di pondok pesantren tersebut. Semakin lama santri pada pondok pesantren tersebut semakin banyak dan sarana prasarananya pun harus semakin banyak juga. Walau demikian, ternyata banyak para dermawan yang mewakafkan tanahnya ke Pondok Pesantren yang akhirnya bisa menyeimbangkan dengan para santri yang semakin banyak. Namun ada beberapa hal 
yang mengganjal disini, yakni tentang pengelolaan tanah wakafnya apakah di kelola secara benar atau tidak serta bagaimana kontribusinya untuk Pondok pesantren tersebut.

\section{LITERATUR REVIEW}

Penelitian tentang pengelolaan dan pendayagunaan tanah wakaf bukanlah masalah baru untuk era yang modern pada saat ini. Banyak peneliti-peneliti yang melakukan penelitian dengan tema tersebut. Namun kebanyakan dari itu belum ditemukan penelitian yang meneliti sekaligus kepada pengelolaan dan pendayagunaan tanah wakaf. Berikut beberapa karya yang terkait permasalahan yang dikaji, yaitu pertama Penelitian yang dilakukan oleh Andi Yusuf. ${ }^{4}$ Penelitian tersebut membahas mengenai sesuai tidakkah pelaksanaan dan pendayagunaan tanah wakaf di Yayasan Uswatun Hasanah menurut hukum Islam dan PP No. 28 tahun 1977. Menurutnya, dalam hukum Islam sudah sesuai karena pelaksanaan dan pendayagunaan sesuai bentuk ibadah mendekatkan diri kepada Allah SWT serta rukun dan syaratnya sudah sesuai sedangkan menurut PP No. 28 tahun 1977 sudah sesuai tetapi belum sempurna karena ada beberapa tanah wakaf yang berstatus akta ikrar wakaf, belum bersertifikat buku tanah wakaf.

Kedua, penelitian yang dilakukan
oleh Agus", tentang "Analisis

4 Andi Yusuf, "Pendayagunaan Tanah Wakaf pada Yayasan Uswatun Hasanah di Desa Lempuyang Kecamatan Anjatan Kabupaten Indramayu (tinjauan hukum Islam dan PP No. 28 Tahun 1977)" Skripsi Tidak Diterbitkan, Program Studi Al- Ahwal Al-Syakhsiyyah Jurusan Syari'ah STAIN Cirebon, 2003.

Agus, "Analisis Pelaksanaan Pengawasan Wakaf di Kabupaten Kuningan" Skripsi diterbitkan, Jurusan Syari'ah Program
Pelaksanaan Pengawasan Wakaf di Kabupaten Kuningan”. Penelitian tersebut bisa dikatakan bahwa pelaksanaan pengawasan sudah sesuai karena dalam peraturan menteri dalam hal pengawasan hanya sebatas pendataan tanah wakaf dan pelaksanaan pengawasan merupakan tugas dari tingkat terbawah sampai ke tingkat pusat yaitu dari tingkat Kecamatan, Kabupaten dan Provinsi/Pusat adapun yang menanganinya adalah Badan Wakaf Indonesia.

Ketiga, oleh Hendriansyah ${ }^{6}$, tentang "Pengelolaan harta wakaf pada perguruan Islam Al-Syukro Universal Ciputat Tangerang Selatan”. Peneitian ini menunjukkan: pengelolaan harta wakaf di Perguruan Islam Al-Syukro Universal dengan cara menerapkan sistem manajemen struktural secara produktif dan profesional. Sistem pengembangan wakaf di Perguruan Islam Al-Syukro Universal dengan memperbaiki gedung yang tidak berfungsi menjadi gedung yang berfungsi, memenej lokasi parkir, memproduktifkan sewa kantin serta mobil antar jemput. Kendala yang dihadapi Perguruan Islam Al-Syukro Universal dalam pengelolaan dan pengembangan adalah terjadinya pro dan kontra antara pengelola dan guru/karyawan pasca diwakafkan kepada Yayasan Dompet Dhuafa Republika dan proses perizinan kepada pemerintah dalam pembangunan gedung baru SMP.

Studi Al-Ahwal Al-Syakhsiyyah STAIN Cirebon, tt.

${ }^{6}$ Hendriansyah, Pengelolaan harta wakaf pada perguruan Islam Al-Syukro Universal Ciputat Tangerang Selatan, Konsentrsi Manajemen Zakat dan Wakaf (ZISWAF), Program Studi Muamalat (Ekonomi Islam), Fakultas Syariah dan Hukum, Universitas Islam Negeri (UIN) Syarif Hidayatullah Jakarta, 1436 H/2015 M. 
Dan keempat, penelitian yang dilakukan oleh Masruchin. ${ }^{7}$ Penelitian tersebut dijelaskan dalam pengelolaan secara produktif di Pondok Modern Darussalam Gontor (PMDG) dilakukan dengan pembangunan sarana dan prasarana untuk mendirikan unit-unit usaha Kopontren La Tansa. Dengan pemberdayaan wakaf uang yang berasal dari infaq wali santri dan iuran santri dan wakaf diri sebagai pengelolanya yang dioperasikan melalui unit-unit usaha pondok yang tergabung dalam Kopontren La Tansa, PMDG nantinya akan mendapatkan penerimaan wakaf uang dari hasil keuntungan unit-unit usaha tersebut. Adapun untuk pengelolaan wakaf tanah sawah, dilakukan secara produktif semi professional. Pengelolaan wakaf secara produktif tercermin dalam pengelolaan tanah wakaf sawah tersebut untuk usaha pertanian dan masih bersifat semi professional dimana tanah-tanah sawah dalam pengelolaannya, yayasan dibantu oleh para pengawas yang disebut wakil nadzir. Para wakil nadzir ini berasal dari daerah tempat sawah tersebut berada. Beberapa tanah ada yang disewakan, dikelola secara bagi hasil, dan ada pula yang digarap sendiri.

Dari keempat topik penelitian yang telah dipaparkan di atas, ternyata belum ada yang meneliti sekaligus pengelolaan dan pendayagunaan tanah wakaf. Dengan meneliti keduanya ternyata dapat dipaparkan kontribusinya tanah wakaf tersebut. Di sinilah letak perbedaan penelitian ini dengan penelitian sebelumnya.

\footnotetext{
7 Masruchin, Wakaf Produktif dan Kemandirian Pesantren (Studi tentang Pengelolaan wakaf Produktif di Pondok Modern Darussalam Gontor Ponorogo). Tesis Program Studi Ilmu Ekonomi Shari'ah Fakultas Syariah Universitas Islam Negeri Sunan Ampel, 2014.
}

\section{METODOLOGI PENELITIAN}

Jenis penelitian yang digunakan yaitu penelitian lapangan (Field Research) yaitu langsung kepada lingkungan kehidupan masyarakat yang sebenarnya dan pada hakekatnya merupakan metode untuk menemukan secara khusus dan realistis apa yang terjadi pada suatu saat di tengah-tengah masyarakat. ${ }^{8} \quad$ Pada penelitian lapangan ini peneliti mengamati kejadian yang terjadi dalam pengelolaan dan pendayagunaan tanah wakaf di Pondok Pesantren Assalafiyah Desa Luwungragi Kecamatan Bulakamba Kabupaten Brebes.

Pendekatan penelitian yang digunakan adalah pendekatan penelitian kualitatif merupakan sebuah metode penelitian yang digunakan dalam mengungkapkan permasalahan dalam kehidupan kerja organisasi pemerintah, swasta, kemasyarakatan, kepemudaan, perempuan, olah raga, seni dan budaya, sehingga dapat dijadikan suatu kebijakan untuk dilaksanakan demi kesejahteraan bersama. ${ }^{9}$ Proses penelitian dilakukan dengan cara mengamati, mencatat, bertanya, menggali sumber yang erat hubungannya dengan peristiwa yang terjadi saat itu. Penelitian Kualitatif ini bersifat deskriptif analisis yang mana hasil dari penelitian ini mampu memberikan gambaran secara menyeluruh, mendalam, tentang suatu keadaan atau gejala yang diteliti. ${ }^{10}$ Sehingga penelitian ini diharapkan mampu untuk memberi gambaran secara rinci, sistematis, dan

\footnotetext{
${ }^{8}$ Kartini Kartono, Penghantar metodologi Riset Sosial (Bandung: Mandar maju) 1990, 32.

9 Imam Gunawan, Metode Penelitian Kualitatif (Teori \& Praktik) (Jakarta: Bumi Aksara, 2015), 80-81.

10 Soerjono Soekamto, Pengantar Penelitian Hukum (Jakarta: UI Press, 1998), 10.
} 
menyeluruh mengenai semua hal yang berkaitan dengan perwakafan tanah yang ada di Pondok Pesantren Assalafiyah.

Sumber data yang diperlukan adalah data primer dan data sekunder. Data primer diperoleh dengan wawancara langsung kepada para informan seperti pengasuh dan pengurus Pondok Pesantren Assalafiyah di Luwungragi Kecamatan bulakamba Kabupaten Brebes. Sedangkan data sekunder yang digunakan adalah dokumentasi/Surat-surat yang berkaitan dengan tanah wakaf tersebut dan bukubuku referensi lainnya yang berkaitan dengan tema yang penulis ambil.

Metode pengumpulan data yang digunakan adalah Observasi, Wawancara (interview), dokumentasi. Pertama, Observasi yaitu dengan mengadakan pengamatan secara langsung ke obyek penelitian untuk memperoleh data yang valid tentang keberadaan dan kontribusi tanah wakaf untuk pengembangan pondok pesantren Assalafiyah. Kedua, Wawancara (interview), wawancara dengan bertatap muka yang memperoleh informasi faktual, untuk menaksir dan menilai kepribadian individu, atau untuk tujuan-tujuan konseling/penyuluhan, tujuan terapetis. ${ }^{11}$ Dalam ini mengadakan tanya jawab secara lisan dan tatap muka dengan responden, seperti: pengurus dan pengasuh Pondok Pesantren Assalafiyah untuk memperoleh data yang berhubungan dengan perwakafan dan pengelolaan serta pendayagunaan tanah wakaf di Pondok Pesantren Assalafiyah.

Dan ketiga, Dokumentasi, yaitu cara data penelitian mengumpulkan suratsurat atau dokumen, tanda-tanda bukti serta peristiwa tertentu dalam suatu kegiatan. Dokumentasi merupakan catatan 187. fenomena, peristiwa, yang sudah berlalu yang dikumpulkan dalam bentuk tulisan, gambar atau karya monumental dari seseorang. Dokumentasi berbentuk gambar misalnya foto, gambar hidup, sketsa dan lain-lain Teknik ini merupakan alat pengumpul data yang utama karena pembuktian hipotesisnya yang diajukan secara logis dan rasional. ${ }^{12}$

\section{KONSEP WAKAF DALAM ISLAM}

Wakaf secara bahasa (lughatan) berasal dari kata waqf yang berarti "terkembalikan" (al-radi'ah), tertahan (tahbis), tertawan (at-tasbil), dan mencegah $\quad\left(a l\right.$-man'u). ${ }^{13}$ Kata al-Waqf dalam bahasa Arab mengandung beberapa pengertian:

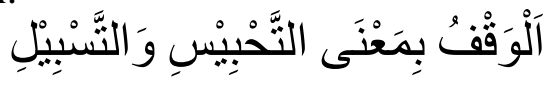

"Menahan, menahan harta untuk diwakafkan, tidak dipindahtangankan". 14

Pengertian wakaf secara terminologi, para ahli fiqih menggunakan dua kata yaitu habas dan wakaf, karena demikian kata yang sering digunakan seperti habasa atau ahbasa dan auqafa untuk menyatakan kata kerjanya. Sedangkan wakaf dan habas adalah kata benda dan jamaknya adalah awqaf, ahbas, dan mahbus. Namun intinya al-habsu maupun al-waqf sama-sama mengandung makna al-imsak (menahan), al-man'u (mencegah), dan at-tamakkust (diam). Disebut menahan karena wakaf ditahan dari kerusakan, penjualan, dan semua

12 S. Margono, Metodologi Penelitian Pendidikan (Jakarta: Rineka Cipta, 2003), 181.

${ }^{13}$ Ismail Nawawi, Fiqh Muamalah Klasik dan Kontemporer (Bogor: Ghalia Indonesia, 2012), 241.

14 Direktorat Jenderal Bimbingan Masyarakat Islam Direktorat Pemberdayaan Wakaf, Fiqih Wakaf, (Jakarta: Departemen Agama RI, 2006), 1. 
tindakan yang tidak sesuai dengan tujuan wakaf.

\section{Dasar Hukum Wakaf}

Wakaf sebagai ibadah yang diistimewakan mempunyai dasar hukum sebagai berikut:

Al-Qur'an

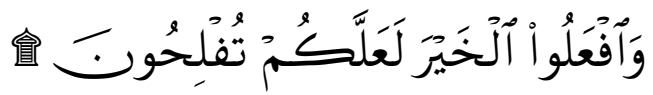

"Dan perbuatlah kebajikan, supaya kamu mendapat kemenangan.",15
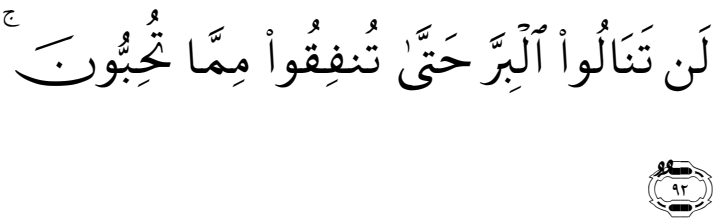

"Kamu sekali-kali tidak sampai kepada kebajikan (yang sempurna), sebelum kamu menafkahkan sehahagian harta yang kamu cintai.",16

$>$ Hadits Nabi

Hadits Nabi Muhammad SAW yang diriwayatkan oleh Imam Muslim:
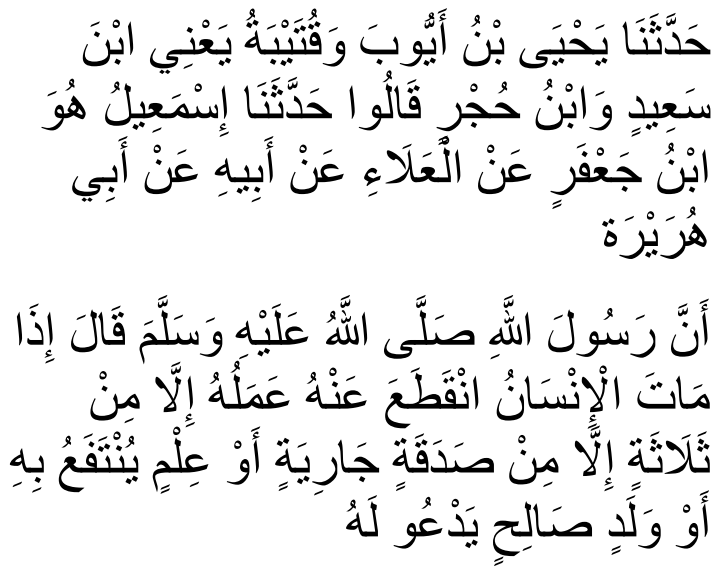

${ }^{15}$ Q.S. Al-Hajj (22): 77

${ }^{16}$ Q.S. Al-Imran (3): 92
"Telah menceritakan kepada kami Yahya bin Ayyub dan Qutaibah yaitu Ibnu Sa'iddan Ibnu Hujr mereka berkata; telah menceritakan kepada kami Isma'il -yaitu Ibnu Ja'far- dari Al 'Ala' dari Ayahnya dari Abu Hurairah, bahwa Rasulullah shallallahu 'alaihi wasallam bersabda: "Apabila salah seorang manusia meninggal dunia, maka terputuslah segala amalannya kecuali tiga perkara; sedekah jariyah, ilmu yang bermanfa'at baginya dan anak shalih yang selalu mendoakannya.",17

Hadits selanjutnya yang diriwayatkan dari Ibnu Umar ${ }^{18}$ tersebut di

17 Sebagian ulama menerjemahkan sedekah jariyah sebagai wakaf, sebab jenis sedekah yang lain tidak ada yang tetap mengalir namun langsung dimiliki zat dan manfaatnya adapun wasiat manfaat walaupun termasuk dalam hadits tetapi sangat jarang. Dengan begitu menerjemahkan sedekah dalam hadits dengan arti wakaf lebih utama.

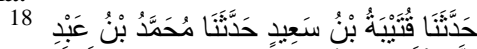

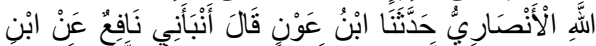

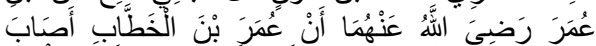

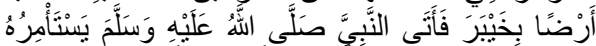

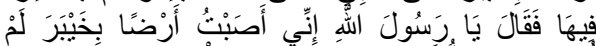

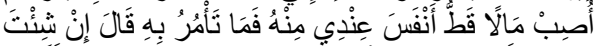

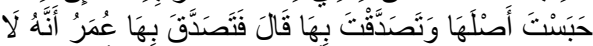

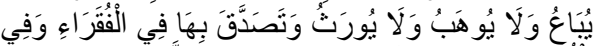

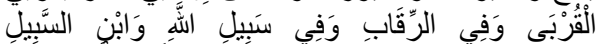

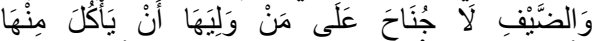

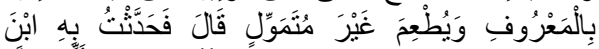

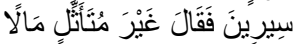

"Telah bercerita kepada kami Qutaibah bin Sa'id telah bercerita kepada kami Muhammad bin 'Abdullah Al Anshariy telah bercerita kepada kami Ibnu 'Aun berkata Nafi' memberitakan kepadaku dari Ibnu'Umar radliallahu 'anhuma bahwa 'Umar bin Al Khaththab radliallahu 'anhu mendapat bagian lahan di Khaibar lalu dia menemui Nabi saw untuk meminta pendapat Beliau tentang tanah lahan tersebut dengan berkata: "Wahai Rasulullah, aku mendapatkan lahan di Khaibar dimana aku tidak pernah mendapatkan harta yang lebih bernilai selain itu. Maka apa yang Tuan perintahkan tentanh tanah tersebut?" Maka Beliau berkata: "Jika kamu mau, 
dalamnya menjelaskan bahwasanya Umar bin Khattab mempunyai sebidang tanah di Khaibar dan bingung bagaimana memanfaatkan tanah tersebut yang akhirnya ia menanyakannya kepada Rasulullah SAW. Kemudian Umar telah menyahut seruan Nabi SAW dengan menyedekahkannya di jalan Allah agar tidak dijual pokoknya, tidak dihibahkan dan tidak diwariskan, Jabir mengatakan tidak ada satu orang sahabat Nabi pun yang ada kemampuan kecuali dia telah memberi wakaf. ${ }^{19}$

Adapun hukumnya yaitu mandub (dianjurkan), dan mandub adalah sesuatu yang dianjurkan oleh syariat untuk mendekatkan diri kepada Allah berupa perbuatan baik yang bukan wajib. ${ }^{20}$

\section{Rukun dan Syarat Wakaf}

1. Waqif (orang yang berwakaf) ialah dia yang mempunyai kecakapan melakukan tabarru', yaitu melepaskan hak milik tanpa imbalan materi. Orang yang dianggap cakap

kamu tahan (pelihara) pepohonannya lalu kamu dapat bershadaqah dengan (hasil buah)nya". Ibnu 'Umar radliallahu 'anhu berkata: "Maka 'Umar menshadaqahkannya dimana tidak dijual, tidak dihibahkan dan juga tidak diwariskan namun dia menshadaqahkannya untuk para faqir, kerabat, untuk membebaskan budak, fii sabilillah, ibnu sabil dan untuk menjamu tamu. Dan tidak berdosa bagi orang yang mengurusnya untuk memakan darinya dengan cara yang ma'ruf (benar) dan untuk memberi makan orang lain bukan bermaksud menimbunnya. Perawi berkata; "Kemudian aku ceritakan hadits ini kepada Ibnu Sirin maka dia berkata: "ghoiru muta'atstsal maalan artinya menggabungkannya dengan harta."

19 Abdul Aziz Muhammad Azzam, Fiqh Muamalat: Sistem Transaksi dalam Fiqh Islam (Jakarta: Amzah, 2010), 397.

20 Abdul Aziz Muhammad Azzam, Fiqh Muamalat Sistem Transaksi dalam Fiqh Islam, 398. bertindak tabarru' adalah berakal sehat, baligh, dan tidak terpaksa.

2. Mauquf (Harta yang diwakafkan), syaratnya pertama, benda itu kekal zatnya dan dapat diambil manfaatnya (tidak musnah karena diambil manfaatnya). Kedua, status hartanya hak milik, meskipun bercampur (musya') yang tidak dapat dipisahkan dari yang lain, maka boleh mewakafkan uang yang berupa modal, berupa saham pada perusahaan. Ketiga, harta wakaf harus segera dapat diterima setelah wakaf diikrarkan. $^{21}$

3. Mauquf alaih (tujuan wakaf) disyaratkan harus sejalan (tidak bertentangan) dengan nilai ibadah, sebab wakaf merupakan salah satu amalan shadaqah dan shadaqah merupakan amalan ibadah. Maka tujuan wakaf harus termasuk kategori ibadah atau sekurang-kurangnya merupakan perkara-perkara mudah menurut ajaran Islam, yakni yang dapat menjadi sarana ibadah dalam arti luas.

4. Shighat waqaf (pernyataan wakaf) ialah bahwa wakaf harus dinyatakan baik dalam bentuk lisan, tulisan, maupun isyarat, bahkan dengan perbuatan. Wakaf dinyatakan sah jika telah ada pernyataan ijab dari waqif, sedangkan kabul dari mauquf alaihi itu tidaklah diperlukan. Shigat dengan isyarat hanya diperuntukkan bagi

${ }^{21}$ Ghazaly, dkk, Fiqh Muamalat (Jakarta: Kencana, 2010), 177. 
orang yang tidak dapat melakukan lisan dan tulisan.

Adapun syarat-syarat wakaf antara lain: ${ }^{22}$

1. Wakaf tidak dibatasi dengan waktu tertentu sebab perbuatan wakaf berlaku untuk selamanya, tidak untuk waktu tertentu.

2. Tujuan wakaf harus jelas. Namun, apabila seseorang meewakafkan sesuatu kepada hukum tanpa menyebutkan tujuannya, hal itu dipandang sah sebab penggunaan benda-benda wakaf tersebut menjadi wewenang lembaga hukum yang yang menerima harta-harta wakaf tersebut.

3. Wakaf harus segera dilaksanakan setelah dinyatakan oleh yang mewakafkan, tanpa digantungkan pada peristiwa yang akan terjadi di masa yang akan datang sebab pernyataan wakaf berakibat lepasnya hak milik bagi yang mewakafkan. Bila wakaf digantungkan dengan kematian yang mewakafkan, ini bertalian dengan wasiat dan tidak bertalian dengan wakaf.

4. Wakaf merupakan perkara yang wajib dilaksanakan tanpa adanya hak khiyar (membatalkan atau melangsungkan wakaf yang telah dinyatakan), sebab pernyataan wakaf berlaku seketika dan untuk selamanya.

\section{Macam-macam Wakaf}

Menurut jumhur ulama wakaf terbagi menjadi dua bagian, yaitu:

22 Ismail Nawawi, Fiqh Muamalah ..., 243. pertama, Waqaf Dzurri (keluarga) disebut juga wakaf khusus dan ahli ialah wakaf yang ditujukan untuk orang-orang tertentu baik keluarga wakif atau orang lain. ${ }^{23}$ Kedua, Waqaf Khairi yaitu wakaf yang ditujukan untuk kepentingan umum dan tidak dikhususkan kepada orang-orang tertentu. ${ }^{24}$

\section{Pengelolaan Wakaf yang Profesional}

Pengelolaan wakaf yang profesional oleh badan wakaf yang dibentuk oleh pemerintah dan harus disesuaikan agar bisa diterima dan cocok dengan struktur dan kebudayaan masyarakat setempat. Keterlibatan infrastruktur yang sudah ada sebelumnya juga penting dalam proses penyesuaian, karena tidak akan efektif jika harus membangun infrastruktur yang baru dan mengabaikan yang sudah ada. Perumusan modal dan mekanisme semacam early warning system untuk mengontrol dan menghindari risiko yang akan mengurangi modal wakaf sangat diperlukan. $^{25}$

Pengelola wakaf disebut dengan istilah "nadzir". Peran nadzir disini sangat penting karena berhasil tidaknya dalam pemanfaatan harta wakaf tergantung dengan nadzir yang mengelolanya. Dengan demikian profesionalisme nadzir menjadi ukuran yang paling penting dalam pengelolaan wakaf jenis wakaf apapun. Atau dalam peraturan perundang-undangnya bisa ditetapkan bahwa nadzir harus berbadan

${ }^{23}$ Wakaf ini sah dan yang berhak untuk menikmati benda wakaf itu adalah orang-orang tertentu saja. Lihat Ghazaly, dkk, Fiqh Muamalat, ..., 179 .

${ }^{24}$ Wakaf inilah wakaf yang hakiki yang
dinyatakan pahalanya akan terus mengalir hingga
wakif itu meninggal dengan catatan benda itu
masih dapat diambil manfaatnya. Lihat Ghazaly,
dkk, Fiqh Muamalat, ...,180
Ismail Nawawi, Fiqh Muamalah Klasik
dan Kontemporer, 249.
dan Kontemporer, 249. 
hukum. Untuk kepentingan lebih luas nadzir harus memiliki cabang atau perwakilan di tingkat kecamatan. ${ }^{26}$ Dalam melaksanakan tugas, nadzir dapat menerima imbalan dari hasil bersih atas pengelolaan dan pengembangan harta benda wakaf yang besarnya tidak melebihi $10 \%$ (sepuluh persen). Nadzir wajib mengelola dan mengembangan harta benda wakaf sesuai dengan tujuan, fungsi, dan peruntukannya. ${ }^{27}$

Dalam rangka pengelola dan pengembangan harta benda wakaf dilakukan oleh nadzir yang memiliki pengetahuan tentang manajeman wakaf yang dilaksanakan sesuai dengan prinsip syariah dan dilakukan secara produktif. Kemudian ia mempunyai pengetahuan tentang prinsip ekonomi dan keuangan syariah, dan mempunyai kemampuan mengelola keuangan secara professional sesuai dengan prinsip syariah, serta mempunyai kemampuan melakukan investasi harta wakaf. ${ }^{28}$

Prinsip manajemen wakaf menyatakan, bahwa wakaf harus tetap mengalir manfaatnya, sesuai dengan hadits nabi SAW, "tahan pokok dan sedekahkan hasilnya". Wakaf seharusnya selalu melibatkan proses pertumbuhan asset dan pertambahan nilai. Dengan kata lain, asset wakaf itu harus berputar, produktif, menghasilkan surplus, dan manfaatnya terus dapat dialirkan tanpa

\footnotetext{
26 Direktorat Jenderal Bimbingan Masyarakat Islam Direktorat Pemberdayaan Wakaf, Pedoman Pengelolaan dan perkembangan Wakaf (Jakarta: Departemen Agama RI, 2013), 80.

27 Dr. Drs. Abd. Shomad, Hukum Islam: Penormaan Prinsip Syariah dalam Hukum Indonesia, (Jakarta: Kencana Prenada Media Group, 2012) 388.

28 Dr. Rozalinda, Manajemen Wakaf Produktif (Jakarta: Rajawali Pers, 2015), 102.
}

mengurangi asset sehingga asset wakaf tidak mengalami penyusutan nilai akibat inflasi, masih dapat diperbarui kembali dari surplusnya. ${ }^{29}$

Pengelola sumber daya manusia nadzir menjadi bagian yang sangat penting dari tugas manajemen organisasi wakaf. Seberapa baik sumber daya manusia dikelola akan menentukan kesuksesan organisasi wakaf di masa akan datang. Sebaliknya, jika sumber daya manusia tidak dikelola dengan baik, efektivitas tidak akan tercapai. Sumber daya manusia nadzir merupakan salah satu unsure yang paling vital bagi organisasi wakaf. Hal ini terjadi karena pertama, sumber daya manusia sangat memengaruhi efisiensi dan efektivitas organisasi, sumber daya manusia merancang dan memproduksi barang dan jasa, mengawasi kualitas, memasarkan produk, mengalokasikan sumber daya financial, serta menentukan seluruh tujuan dan strategi organisasi. Kedua, sumber daya manusia merupakan pengeluaran utama organisasi dalam menjalankan bisnis. Karena pentingnya manajemen sumber daya manusia ini, bila diabaikan, organisasi tidak akan berhasil mencapai tujuan dan sasaran. ${ }^{30}$

Dalam perwakafan, pengelola wakaf atau nadzir sangat membutuhkan manajemen dalam menjalankan tugasnya. Manajemen ini digunakan untuk mengatur kegiatan pengelola wakaf dan menjaga hubungan baik antara nadzir, waqif, dan masyarakat. Manajemen wakaf merupakan proses membuat perencanaan, pengorganisasian, kepemimpinan, dan pengawasan berbagai usaha dari mencapai

29 Dr. Rozalinda, Manajemen Wakaf Produktif, 72.

30 Dr. Rozalinda, Manajemen Wakaf Produktif, 102. 
sasaran. Oleh karena itu, setiap manajer wakaf atau nadzir harus menjalankan keempat fungsi tersebut di dalam organisasi sehingga hasilnya merupakan satu kesatuan yang sistematik, misalnya setiap orang bisa merencanakan dan menyusun pekerjaannya, tetapi mereka belum bisa di anggap sebagai manajer bila kemampuannya hanya sebatas merencanakan tanpa bisa melaksanakan. ${ }^{31}$

\section{HASIL PENELITIAN}

\section{Wakaf di Pondok Pesantren Assalafiyah}

Berdasarkan studi lapangan yang telah dilakukan peneliti bahwasanya asal kepemilikan tanah pada Pondok Pesantren Assalafiyah merupakan milik pribadi dari keluarga Kiai Subhan Ma'mun dan pada tahun 2015 telah resmi diwakafkan oleh Kiai Subhan yang dipergunakan untuk keperluan pondok pesantren tersebut. Tanah yang dibangun untuk pondok pesantren tersebut tidak hanya berasal dari tanah wakaf tetapi ada sebagian tanah yang dibeli oleh Kiai Subhan dimana dua bagian itu dari wakaf dan yang tiga bagian lainnya dapat membeli yang keseluruhan tanahnya ada lima bagian. Walau ada sebagian yang dapat membeli sendiri tetapi sekarang semua sudah disertifikatkan menjadi tanah wakaf. $^{32}$ Kemudian, hari demi hari banyak warga daerah Brebes yang mewakafkan sebagian tanahnya untuk pendirian Pondok Pesantren Assalafiyah. Tanah yang diwakafkan itu juga diperuntukkan untuk pengembangan pondok pesantren sesuai dengan ikrar wakaf. Hampir semua

Produktif, 74.

31 Dr. Rozalinda, Manajemen Wakaf

Kasnadi, pengelola wakaf sawah pada tanggal 8 April 2017 pukul 17.20. bangunan di Pondok Pesantren Assalafiyah berasal dari tanah wakaf. Bahkan tanah milik pribadi Kiai Subhan telah diwakafkan ke pondok pesantren.

Semakin berjalannya waktu, pengasuh Pondok Pesantren Assalafiyah yakni Kiai Subhan mulai dikenal oleh masyarakat Brebes dan sekitarnya yang menyebabkan semakin banyak santri baik putra maupun putri yang berminat untuk menuntut ilmu di tempat tersebut. Pondok pesantren tersebut juga semakin maju dan bertambah banyak santrinya. Begitu pun banyak juga orang-orang di Luwungragi dan sekitarnya yang ingin mewakafkan sebagian hartanya agar dimanfaatkan sebaik-baiknya di jalan Allah. Bukan hanya wakaf yang berupa tanah tetapi juga ada yang mewakafkan hartanya berupa sawah yang digunakan untuk pengembangan pondok pesantren. Pondok Pesantren Assalafiyah mendapatkan wakaf sawah yang pertama kali dari $\mathrm{H}$. Abdul Majid dengan luas sawahnya 7.000 $\mathrm{m}^{2}$ pada tahun $1980 .{ }^{33}$ Kemudian banyak juga para dermawan lainnya yang mewakafkan sebagian hartanya untuk Pondok Pesantren Assalafiyah.

Jumlah luas keseluruhan wakaf yang berupa sawah dari berbagai wakif yaitu $20.150 \mathrm{~m}^{2}$ atau sekitar kurang lebih 2 hektar. Sedangkan tanah wakaf yang berupa tanah kosong yang sekarang sudah berbentuk bangunan Pondok Pesantren Assalafiyah I mencapai kurang lebih $7.520 \mathrm{~m}^{2}$ dan wakaf tanah kosong untuk pembangunan Pondok Pesantren Assalafiyah II yaitu $2.728 \mathrm{~m}^{2}$ yang diwakafkan oleh $\mathrm{H}$. Wardhoni. Wakaf yang berada di Luwungragi itu bukan hanya berupa tanah saja tetapi ada yang

33 Hasil wawancara dengan Bapak Kasnadi, pengelola wakaf sawah pada tanggal 8 April 2017 pukul 17.20. 
berupa sawah. Wakaf tanah yang berada di Luwungragi mempunyai luas sekitar kurang lebih $5.700 \mathrm{~m}$, sedangkan wakaf yang berupa sawah semuanya kurang lebih ada 2 hektar. Dan lokasi sawah tersebut bukan hanya berada di Desa Luwungragi tetapi ada juga yang berada di Desa Siasem dan Pakijangan. Sementara wakaf yang berupa tanah itu dimanfaatkan untuk pembangunan pondok dan jalan yang menuju ke pondok. Sedangkan wakaf yang berupa sawah itu di tanami berbagai macam sayur-sayuran dan hasilnya untuk pengembangan Pondok Pesantren Assalafiyah.

Seiring berjalannya waktu ketika zaman ini mulai modern dan banyak sekali pondok pesantren yang bukan hanya mondok dengan belajar kitab saja tetapi diiringi dengan menempuh pendidikan formal. Dari sini banyak permintaan dari masyarakat untuk menerima santri yang mondok dengan menempuh pendidikan formal juga. Tetapi Kiai Subhan belum ingin menerima permintaan dari masyarakat. Dan belum lama kemudian pada acara akhirussanah pondok yang didatangi oleh Kiai Nurul Huda Jazuli, beliau memberikan saran membuka pendaftaran untuk santri yang ingin belajar kitab dan belajar pada pendidikan formal juga. Pada saat itu Kiai Subhan hanya mengiyakan dengan menjawab Insya Allah dan beliau tidak ingin membangun pondok untuk santri yang menempuh pendidikan formal dan belajar kitab di daerah Luwungragi. Tak lama kemudian ada seseorang yang ingin mewakafkan sebagian tanahnya untuk Pondok Pesantren Assalafiyah.

Seorang dermawan yang ingin mewakafkan sebagian tanah wakafnya itu bernama H. Wardhoni. H. Wardhoni merasa menemukan tempat yang tepat untuk mewakafkan tanahnya. Ketika beberapa waktu lalu, dia sempat pernah kesulitan mencari sosok yang amanah. Karena sebelumnya $\mathrm{H}$. Wardhoni pernah akan memberikan wakaf tersebut kepada orang lain, tapi digagalkan karena pertemuan dengan orang itu meninggalkan kesan tidak amanah di mata $\mathrm{H}$. Wardhoni. Akhirnya tanah tersebut di wakafkan kepada Pondok Pesantren Assalafiyah melalui keponakannya. $H$. Wardhoni mewakafkan tanahnya untuk Pondok Pesantren Assalafiyah dengan luas 2.728 $\mathrm{m}^{2}$ yang berada di daerah Saditan Brebes dan sekarang sudah bersertifikat tanah wakaf.

Dengan adanya wakaf dari $\mathrm{H}$. Wardhoni tersebut akhirnya Kiai Subhan bisa menerima permintaan warga untuk merealisasikan pondok pesantren untuk bisa menerima santri yang juga bersekolah formal. Karena pondok pesantren tersebut merupakan cabang dari Pondok Pesantren Assalafiyah maka pengasuh dari pondok pesantren tersebut tetap dipegang oleh Kiai Subhan Ma'mun dan diberi nama Pondok Pesantren Assalafiyah II.

Kemudian ketika pembangunan itu berlangsung ada seseorang yang dari Desa Keboledan menyumbangkan uangnya hingga mencapai 1,5 Miliar yang bernama H. Sanjir. Dengan sangat kebetulan dan tanpa ada keragunan apapun akhirnya uang tersebut bisa membantu pembangunan Pondok Pesantren Assalafiyah II. Mengingat tujuan dari dibentuknya Pondok Pesantren Assalafiyah II ini untuk bisa menerima santri yang juga menempuh pendidikan formal maka sistem pembelajarannya pun berbeda dengan Pondok Pesantren Assalafiyah I. Dimana Pondok Pesantren Assalafiyah II tidak menggunakan sistem salaf seperti yang ada di Pondok Pesantren Assalafiyah I. 
Pondok Pesantren Assalafiyah II mulai dibangun pada tahun 2013 dan dibuka pada tahun 2015 yang ketika itu baru menerima santri putra saja, belum bisa menerima santri putri sebelum pembangunannya selesai. Setelah pembangunan selesai banyak santri putri yang berminat untuk nyantri disana. Hingga sampai sekarang santrinya sudah mencapai kurang lebih 200 santri putra dan putri.

\section{Pengelolaan Wakaf di Pondok Pesantren Assalafiyah}

Setelah penulis melakukan penelitian dengan cara observasi dan wawancara kepada informan-informan yang mengetahui tentang tanah wakaf di Pondok Pesantren Assalafiyah ternyata di Pondok Pesantren Assalafiyah Brebes memanfaatkan tanah wakaf untuk membangun madrasah dan fasilitas lainnya untuk membantu santri dalam menuntut ilmu di Pondok Pesantren Assalafiyah. Dari tanah wakaf tersebut telah berdiri bangunan-bangunan di sekitar Pondok Pesantren Assalafiyah. Mulai dari pondok putra yang terdiri dari empat komplek begitupun dengan pondok putri sendiri. Tetapi, pondok putri saat ini hanya terdiri dari dua komplek. Selain bangunan komplek putra dan putri, juga telah dibangun aula dalail al-khairat, mushola pondok, madrasah untuk santri putra dan putri, kantor asātiż dan ruang tamu untuk tempat para santri yang dijenguk oleh orang tua dan kerabatnya.

Kemudian selain wakaf tanah seperti yang telah diuraikan pada bab sebelumnya bahwa tidak semua tanah wakaf berada di Desa Luwungragi dan tanahnya bukan hanya tanah kosong tetapi ada juga yang wakaf berupa sawah dengan luasnya yang berbeda-beda karena banyak orang dermawan yang mewakafkan sebagian hartanya untuk Pondok Pesantren Assalafiyah. Ini menunjukkan adanya perkembangan wakaf di Pondok Pesantren Assalafiyah yang awalnya menerima wakaf berupa tanah kosong tetapi sekarang telah menerima wakaf berupa sawah. Wakaf sawah tersebut dimanfaatkan dengan menggunakan sistem pengelolaan dimana nadzir memberikan tanah wakaf sepenuhnya kepada pihak lain langsung yaitu kepada warga Desa Luwungragi. Dalam pasal 1 ayat 5 yang berbunyi "Pengelolaan dan Pengembangan harta benda wakaf adalah proses memproduktifkan harta benda wakaf baik dilakukan oleh nadzir sendiri atau bekerja sama dengan pihak lain untuk mencapai tujuan wakaf". ${ }^{34}$ Namun dalam pengelolaan wakafnya tetap ada persetujuan dari pengurus yayasan Azma Assalafiyah.

Berdasarkan wawancara dengan Bapak Ali Mubarok sebagai wakil sekretaris yayasan mengungkapkan bahwa pengurus yayasan pada Pondok Pesantren Assalafiyah juga berperan sebagai pengurus nadzir organisasi pada pondok pesantren tersebut. Untuk menjadi nadzir dalam hal ini nadzir organisasi karena Pondok Pesantren Assalafiyah merupakan suatu yayasan atau lembaga yang mempunyai harta wakaf tidak sedikit yang dalam pengelolaannya juga dilakukan secara produktif maka membutuhkan nadzir organisasi. Nadzir organisasi pada Pondok Pesantren Assalafiyah itu biasanya yang mempunyai yayasan seperti apa yang telah dijelaskan di atas bahwa nadzir organisasi merupakan pengurus yayasan itu sendiri.

${ }^{34}$ Peraturan Badan Wakaf Indonesia No. 4 tahun 2010 tentang Pedoman Pengelolaan dan Pengembangan Harta Benda Wakaf. 
Untuk menjadi seorang nadzir minimal seseorang tersebut mempunyai akta notaris dan SK MENKUMHAM. Seseorang yang ingin menjadi nadzir wakaf Pondok Pesantren Assalafiyah mengajukan diri kepada yayasan kemudian dari pihak yayasan ke KUA untuk mengajukan permohonan pengesahan nadzir setelah diajukan lalu disahkan oleh KUA. Setelah sudah ada pengesahan dari KUA seseorang tersebut sudah sah menjadi nadzir wakaf Pondok Pesantren Assalafiyah dan dapat menerima dan mengelola wakaf sebagaimana mestinya seorang nadzir. ${ }^{35}$

Sedangkan yang menerima wakaf dalam hal ini nadzir dan yang mempunyai tanggung jawab penuh yaitu Kiai Subhan itu sendiri hanya menerima laporan hasil dari tanaman yang ditanam di tanah wakaf yang berupa sawah tersebut. Walau demikian Kiai Subhan tetap mengawasi tanah wakaf tersebut dengan dibantu oleh pengurus lainnya. Dan hasil dari panen tersebut di bagi dua untuk yang membantu mengelola dalam hal ini petani yang mengurus sawah dan untuk pengembangan Pondok Pesantren Assalafiyah. Dari situlah praktek pengelolaan tanah wakaf yang ada di Pondok Pesantren Assalafiyah.

Dalam hal pengelolaan tanah wakaf sawah semua diserahkan kepada petani sawah untuk dikelola dengan baik dimana mereka menanami sawah tersebut dengan berbagai macam tanaman seperti padi, bawang, cabai dan sayur-sayuran sesuai keadaan cuaca yang berada di desa tersebut. Kondisi tanah di Desa Luwungragi yang memungkinkan untuk dapat ditanami berbagai tanaman ternyata

35 Hasil wawancara dengan Bapak Ali Mubarok, Wakil Sekretaris Yayasan Azma Assalafiyah, pada tanggal 3 Mei 2017 pukul 15.35. memang benar. Tanaman yang ditanam di atas sawah wakaf selalu menghasilkan panen yang memuaskan dan Alhamdulillah dalam mengelola sawahnya belum ada kendala apapun. Warga disekitar Pondok Pesantren Assalafiyah mayoritas penduduknya bekerja sebagai petani yang dapat membantu pihak pondok pesantren dalam mengelola sawah tersebut.

Wakaf sawah tersebut ditangani oleh warga Luwungragi semua tetapi karena tanah wakafnya tidak semua berada di Luwungragi maka sebagian warga ada yang menangani sawah di daerah Pakijangan. Sawah yang berada di Pakijangan di tangani oleh Bapak Salim sedang yang di Luwungragi ditangani oleh Bapak Kasnadi dan Bapak Sukino. Untuk lebih mengoptimalkan pengelolaan sawah, Pengasuh Pondok Pesantren Assalafiyah menentukan salah satu petani untuk dijadikan ketua petani yang bertanggung jawab penuh atas sawah tersebut.

Pengelolaan tanah wakaf yang ada pada Pondok Pesantren Assalafiyah tetap sah sesuai prinsip syariah dan dilakukan secara produktif. Dalam hal ini tanah wakaf berupa sawah selalu ditanami berbagai macam tanaman dengan demikian wakaf tersebut bisa produktif. Dalam UU No. 41 tahun 2004 tentang Wakaf menjelaskan bahwa:

Pasal 42: Nadzir wajib mengelola dan mengembangkan harta benda wakaf sesuai dengan tujuan, fungsi, dan peruntukannya.

Pasal 43: (1) Pengelolaan dan pengembangan harta benda wakaf oleh nadzir sebagaimana dimaksud dalam pasal 42 dilaksanakan sesuai dengan prinsip syariah. (2) Pengelolaan dan pengembangan harta benda wakaf sebagaimana di maksud pada ayat (1) dilakukan secara produktif. 
Berdasarkan wawancara peneliti dengan penggarap sawah wakaf mengatakan bahwa sawah pada Pondok Pesantren Assalafiyah yang dikelola petani setempat hasilnya dibagi dua. Tanaman yang ditanam petani akan menghasilkan panen dan biasanya dalam waktu dua bulan sekali tanaman pada sawah tersebut membuahkan hasil. ${ }^{36}$ Tetapi untuk tanaman padi waktu dua bulan tidaklah cukup karena padi hanya bisa dipanen ketika sudah berusia 100 hari. Dengan demikian panen yang dilakukan petani tidak setiap saat dua bulan sekali karena untuk tanaman padi membutuhkan waktu 100 hari atau tiga bulan 10 hari.

Tanaman hasil panennya baik padi maupun bawang dijual kepada juragan bawang maupun juragan padi yang ada di Luwungragi. Kemudian uang hasil panen tersebut diserahkan terlebih dahulu kepada Bapak Kasnadi selaku mandor petaninya. Ketika uang tersebut sudah terkumpul dari hasil panen pada beberapa sawah kemudian diserahkan kepada Kiai Subhan untuk pengembangan Pondok Pesantren Assalafiyah. Uang tersebut diserahkan penuh kepada Kiai Subhan karena beliau yang mengatur semua pengeluaran dan pemasukan hasil wakafnya. Menurut Kiai Subhan selaku pengasuh Pondok Pesantren Assalafiyah mengatakan bahwa hasil sawahnya dapat mencapai kurang lebih 20 jutaan dalam setahun. Dan dari hasil tersebut dibagi dua antara untuk pengembangan pondok pesantren dan untuk para penggarap sawah. ${ }^{37}$

36 Hasil wawancara dengan Bapak Kasnadi, pengelola sawah pada tanggal 8 April 2017 pukul 17.20.

${ }^{37}$ Hasil wawancara dengan Kiai Subhan Ma'mun, Pengasuh Pondok Pesantren Assalafiyah, pada tanggal 21 Maret 2017 pukul 17.40.
Hasil panen tanaman padi selain dijual kepada juragan padi biasanya pada saat bulan Ramad̄ān padi tersebut diserahkan kepada pihak pengurus pondok pesantren untuk dijadikan beras yang nantinya akan dimanfaatkan untuk kebutuhan di bulan Ramadān terutama untuk berbuka dan sahur.

Sistem bagi hasil dari tanah tersebut, pada bagian hasil yang didapatkan petani tidak hanya sebagai upah dari apa yang sudah dikerjakan petani melainkan sebagai dana dalam memenuhi kebutuhan bercocok tanam seperti halnya bibit dan lain sebagainya. Sedangkan penggunaan untuk tanaman di dapatkan dari Kiai Subhan.

Hasil panen tersebut tadi diserahkan kepada pengurus wakaf dan dikelola untuk pengembangan Pondok Pesantren Assalafiyah tetapi hasil ini masih di-tașorruf-kan kepada Pondok Pesantren Assalafiyah I dan belum sampai kepada Pondok Pesantren Assalafiyah II dikarenakan masih banyak bangunanbangunan yang akan direnovasi. Bangunan tersebut kini sudah berdiri dari mulai pondok putri komplek II, madrasah aula dan lain-lain. Untuk saat ini pondok pesantren masih membangun mushola yang berada di komplek pondok putra. Walaupun ada sedikit kekurangan tetapi pengurus Pondok Pesantren Assalafiyah masih bisa mengatasinya. Sehingga dari hasil wakaf tersebut mampu menutup kekurangan-kekurangan bangunan.

Disamping bangunan tersebut dari hasil wakaf ada juga sumbangansumbangan sukarela dari warga Luwungragi dan sekitarnya guna membantu apa saja yang kurang. Bukan hanya warga desa saja yang berpartisipasi untuk membantu pembangunan pondok pesantren tetapi para santri juga antusias menyalurkan dana kepada Pondok 
Pesantren Assalafiyah. Walaupun tidak seberapa tetapi mereka senang bisa berpartisipasi dalam pembangunan pondok pesantren karena mereka sudah merasa memiliki pondok pesantren tersebut yang akhirnya mereka mempunyai rasa ingin menjaga dan selalu memberikan yang terbaik untuk Pondok Pesantren Assalafiyah. Selain itu juga pengurus pondok pesantren pernah mengadakan iuran wajib santri guna membantu pembangunan pondok seperti pada saat membangun pondok putri komplek II, setiap santri membayar iuran wajib sebesar Rp. 100.000,- yang langsung dikumpulkan kepada pengurus untuk sedikit membantu kekurangannya. ${ }^{38}$

Tentu saja harapan umat Islam pasti dalam pengelolaan tanah wakaf itu dapat dilakukan sebaik-baiknya dan dikelola dengan semaksimal mungkin agar manfaatnya lebih bisa dirasakan secara maksimal sebagaimana keinginan pewakif. Setiap harta wakaf hendaklah diusahakan hasil dan pemanfaatannya secara maksimal tentunya ini yang harus dilakukan oleh nadzir agar peruntukkan yang ada di ikrar wakaf itu tercapai. Agar dalam mengelola tanah wakaf itu maksimal maka diperlukan adanya pengawasan, penjagaan dan pengelolaan harta wakaf yang baik.

Dalam hal pengawasan tanah wakaf di Pondok Pesantren Assalafiyah dilakukan oleh pengasuh langsung yaitu oleh Kiai Subhan Ma'mun dan juga dibantu pengurus yang lain yang sekiranya mampu. Pengawasan tersebut dilakukan agar tidak terjadi penyelewengan dan ketidaksesuaian peruntukkan tanah wakaf. Dikarenakan

38 Hasil wawancara dengan Kang Shodiqin, Kepala pondok putra Assalafiyah, pada tanggal 29 Maret 2017 pukul 13.30.
Pondok Pesantren Assalafiyah masih menggunakan ajaran Imam Syafi'i yakni mengedepankan tujuan diwakafkannya tanah wakaf tersebut. Apa yang ditulis dalam ikrar wakaf itulah yang menjadi acuan dalam menggunakan harta wakaf tersebut. Dalam ikrar wakaf tersebut pastinya tidak lepas untuk pengembangan Pondok Pesantren Assalafiyah.

Memang pengurus wakaf tidak mendapatkan imbalan apa-apa tetapi yang mengelola wakaf tersebut mendapat sebagian dari wakaf tersebut. Sebagaimana yang telah dijelaskan di atas bahwa hasil dari panen sawah tersebut sebagian diserahkan ke pondok pesantren sebagiannya lagi diserahkan kepada petani yang mengelola sawah tersebut. Walaupun tidak ada imbalan tetapi pengurus wakaf mempunyai kewajiban untuk mengawasi, memakmurkan dan selalu berupaya untuk semaksimal mungkin mendapatkan hasil dari wakaf itu sendiri. Sesuai pasal 42 yang berbunyi: "Nadzir wajib mengelola dan mengembangkan harta benda wakaf sesuai dengan tujuan, fungsi, dan peruntukannya". ${ }^{39}$ Melihat prinsip hukum Islam dan Undang-undang ternyata fungsi nadzir disini sangat diperlukan agar peruntukkan wakaf dapat terlaksana.

Dalam pengelolaan tanah wakaf pada Pondok Pesantren Assalafiyah selalu berjalan dengan baik. Pengelolaan harta wakaf yang berupa tanah kosong di kelola dengan cara membangun tempat-tempat untuk fasilitas santri dalam menuntut ilmu seperti tempat tinggal santri, aula, mushola, madrasah dan lain-lain. Menurut Kiai Subhan kegiatan pembangunan pondok pesantren selalu lancar walau pernah ada sedikit kendala tetapi dapat dikendalikan dengan baik. Pernah suatu

\footnotetext{
${ }^{39}$ UU No. 41 tahun 2004 tentang Wakaf.
} 
ketika sedang membangun salah satu bangunan pondok pesantren tetapi merasa kekurangan dana akhirnya dari pihak pengurus pondok pesantren menariki iuran kepada santri putra maupun putri sebesar Rp. 100.000,-. Walau demikian santri tidak merasa keberatan karena bagi mereka Pondok Pesantren Assalafiyah sudah menjadi rumah mereka. Selain itu juga disamping dari hasil pemanfaatan tanah wakaf banyak para dermawan yang antusias menyumbangkan uangnya untuk membantu dalam proses pembangunan.

Sedangkan dalam pengelolaan tanah wakaf berupa sawah yang di Pakijangan tanahnya hanya menerima perairan dari air hujan saja dan hanya mampu ditanamani padi. Walau demikian tidak ada alasan untuk tidak menjadikan wakafnya tidak produktif. Dengan adanya wakaf sawah yang berada di Luwungragi mampu menjadikannya wakaf yang produktif dengan ditanami berbagai jenis rempah-rempah.

\section{Pendayagunaan Wakaf di Pondok Pesantren Assalafiyah}

Pada zaman sekarang perubahan sosial sangatlah pesat tentunya dalam hal pendayagunaan tanah wakaf. Semakin modern bangsa Indonesia semakin banyak inovasi-inovasi yang digunakan oleh bangsa Indonesia agar manfaat tanah wakaf semakin produktif dan bisa dirasakan. Untuk bisa membuktikan eksistensi pendayagunaan tanah wakaf menurut hukum Islam dan UU No. 41 tahun 2004 tentang Wakaf ditengahtengah perubahan sosial saat ini, tentu sangat membutuhkan analisis yang kritis terhadap pendayagunaan tanah wakaf tersebut.

Telah dijelaskan bahwa seseorang yang mewakafkan hartanya semata-mata hanya mengharap keridhaan Allah SWT dengan memberikan harta wakaf kepada Sang Pemberi Harta yakni Allah SWT. Jangan sampai dipahami hanya sebagai amalan dunia saja yang diberikan kepada seseorang. yayasan atau lembaga tertentu. Dengan mewakafkan hartanya seseorang akan menyadari bahwa semua yang ada pada dirinya hanya titipan sementara dan akan kembali kepada Allah SWT. Karena wakaf merupakan bentuk tasharruf maka ketika hanya dengan adanya ijab saja sudah dianggap sah meskipun tidak diikuti qabul dari penerima wakaf. Dalam penggunaan harta wakaf itu harus sesuai dengan peruntukkan pada waktu ikrar, tidak boleh bertentangan dengan apa yang diikrarkan.

Dalam hal pendayagunaan tanah wakaf di Pondok Pesantren Assalafiyah ini tidak bisa dibangun atau di dayagunakan untuk kegiatan sosial dikarenakan tanah wakaf itu masih berada di desa. Dalam artian tanah wakaf di Pondok Pesantren Assalafiyah tidak didayagunakan tetapi tidak memungkinkan tanah wakaf tersebut tidak dikembangkan dengan baik. Kalau seandainya tanah wakaf itu berada ditengah-tengah perkotaan pastilah banyak peluang untuk memanfaatkan tanah wakaf tersebut seperti untuk pembangunan gedung serbaguna, rukoruko ataupun kios-kios, sebagaimana yang dinyatakan oleh Kiai Subhan ketika proses wawancara dilakukan.

Tanah yang diwakafkan berupa sawah yang kurang lebih luasnya mencapai 2 hektar yang berada di sekitar Pondok Pesantren Assalafiyah harus dimanfaatkan sebagai lahan bercocok tanam sebagaimana intruksi dari pihak wakif agar tanah wakaf tersebut tidak dibiarkan segitu saja sehingga tidak bermanfaat. Salah satu pemanfaatan tanah wakaf tersebut dilakukan dengan bercocok tanam 
oleh para petani diantara padi, sayursayuran dan rempah-rempah. Hasil dari pemanfaatan sawah tersebut mencapai mencapai 20 juta pertahun dan kemudian hasilnya di-taṣorruf-kan untuk pengembangan Pondok Pesantren Assalafiyah I.

Dengan demikian, bahwa pendayagunaan tanah wakaf yang ada di Pondok Pesantren Assalafiyah sudah sesuai dengan hukum Islam karena pendayagunaan tanah wakaf pada Pondok Pesantren Assalafiyah itu merupakan suatu bentuk ibadah dengan tujuan untuk mendapatkan ridha dari Allah SWT dan untuk mendekatkan diri kepada Allah SWT. Dalam ikrar wakaf juga tidak disebutkan secara khusus untuk mushola pondok ataupun tempat-tempat lainnya, tetapi hanya menyebutkan untuk pengembangan Pondok Pesantren Assalafiyah. Nadzirnya pun tidak mendapatkan upah sedikitpun tetapi tetap memberikan sebagian hasil dari tanah wakaf kepada yang menggarap sawah yang ditanami di atas tanah wakaf. Dalam artian bisa saling membantu sesama muslim. Adapun pendayagunaan menurut UU No. 41 tahun 2004 sudah sesuai tetapi belum sempurna dikarenakan ada beberapa wakaf sawah yang belum mempunyai sertifikat tanah wakaf dan masih berbentuk akta ikrar wakaf.

\section{Kontribusi Tanah Wakaf pada Pondok Pesantren Assalafiyah}

Wakaf merupakan energi dahsyat para umat, telah banyak yang mampu memperbaiki citra ekonomi umat. Sekecil apa pun wakafnya pasti akan bermanfaat. Pada saat ini dalam pengelolaan wakaf berjalan semakin produktif. Tanah wakaf produktif lebih menekankan kepada hasil tanah tersebut, tetapi tetaplah menahan atau melestarikan harta tersebut sesuai dengan tujuan dan fungsi wakaf yang telah ditentukan wakif dalam ikrar wakaf sesuai syariat Islam. Tanah wakaf seluas $21.000 \mathrm{~m}^{2}$ dimanfaatkan untuk bercocok tanam yang diamanatkan kepada petani sawah di Desa Luwungragi. Dalam dua atau tiga bulan sekali dari proses bercocok tanam menghasilkan panen dan hasilnya diserahkan kepada pihak Pondok Pesantren Assalafiyah dalam hal ini Kiai Subhan.

Wakaf pada Pondok Pesantren Assalafiyah masih mengelola wakafnya sesuai dengan ikrar wakaf yang dilakukan karena disini wakaf muayan dimana wakaf tersebut tidak boleh digunakan selain dari ikrar wakaf tersebut. Kecuali wakaf jihad yang kontribusinya untuk kemaslahatan ummat yang dibutuhkan saat itu, sebagaimana yang diungkapkan oleh Kiai Subhan ketika proses wawancara.

Telah terbukti bahwa wakaf pada Pondok Pesantren Assalafiyah sangat berpengaruh untuk pengembangan pondok pesantren. Yang sebelum adanya wakaf pondok pesantren masih belum cukup direnovasi tetapi sekarang bangunan pada pondok pesantren sudah lebih bagus dari sebelumnya. Sawah wakaf yang setiap tahun menghasilkan panen kurang lebih 5 sampai 6 kali mampu menmbantu dalam pembangunan pondok pesantren. Walau tidak setiap saat membangun tetapi hasil wakaf masih bisa dimanfaatkan untuk keperluan pondok pesantren lainnya.

Kontribusi tanah wakaf sebagai salah satu sumber pemasukan pada Pondok Pesantren Assalafiyah berharap dapat memberikan sumbangsih dalam meningkatkan kesejahteraan ekonomi umat di Pondok Pesantren Assalafiyah. Disamping untuk pengembangan Pondok Pesantren Assalafiyah juga dimanfaatkan untuk kebutuhan sehari-hari bagi santri 
baik putra maupun putri pada bulan Ramadān dengan memanfaatkan salah satu hasil panen sawah yang berupa padi untuk kebutuhan makanan para santri.

\section{KESIMPULAN}

Berdasarkan hasil penelitian di atas, maka dapat diambil tiga kesimpulan yaitu: Pertama, Pengelolaan harta wakaf di Pondok Pesantren Assalafiyah sudah sesuai dengan prinsip syariah yang mana harta wakaf pada Pondok Pesantren Assalafiyah tidak dijual, diwariskan dan dihibahkan melainkan dikelola dengan baik dan bermanfaat. Wakaf yang berupa tanah kosong dikelola untuk membangun fasilitas pondok pesantren sedangkan untuk tanah wakaf berupa sawah dikelola secara produktif dan profesional.

Kedua, Pendayagunaan tanah wakaf pada Pondok Pesantren Assalafiyah sudah dimanfaatkan dengan baik sesuai dengan ikrar wakaf antara wakif dan nadzir dimana tanah wakafnya didayagunakan untuk sawah. Dalam hal lain mayoritas penduduknya juga sebagai petani yang mendukung untuk pemanfaatan tanah wakaf berjalan dengan baik dan professional.

Ketiga, Dengan melihat pengelolaan dan pendayagunaan wakaf yang produktif pada Pondok Pesantren Assalafiyah membuktikan bahwa kontribusi wakaf disini sangat mempengaruhi pengembangan pondok pesantren tersebut. Dengan adanya wakaf produktif mampu membantu pihak pondok pesantren dalam mengembangkan pondok pesantren dan memperbaiki apa saja yang sekiranya perlu direnovasi. Selain itu juga membuka peluang pekerjaan untuk penduduk Desa Luwungragi sekitar pondok pesantren tersebut yang mayoritas penduduknya sebagai petani.

\section{DAFTAR PUSTAKA}

Agus, "Analisis Pelaksanaan Pengawasan Wakaf di Kabupaten Kuningan” Skripsi diterbitkan. Jurusan Syari'ah Program Studi Al-Ahwal Al-Syakhsiyyah STAIN Cirebon, $\mathrm{tt}$.

Azzam, Abdul Aziz Muhammad. Fiqh Muamalat: Sistem Transaksi dalam Fiqh Islam. Jakarta: Amzah. 2010.

Basyir, Ahmad Azhar. Hukum Islam tentang Wakaf, Ijarah, dan Syirkah. Bandung: PT Al-Ma'arif. 1987.

Direktorat Jenderal Bimbingan Masyarakat Islam Direktorat Pemberdayaan Wakaf, Fiqih Wakaf. Jakarta: Departemen Agama RI. 2006

Direktorat Jenderal Bimbingan Masyarakat Islam Direktorat Pemberdayaan Wakaf, Pedoman Pengelolaan dan perkembangan Wakaf. Jakarta: Departemen Agama RI. 2013

Ghazaly, dkk. Fiqh Muamalat. Jakarta: Kencana. 2010.

Gunawan, Imam. Metode Penelitian Kualitatif (Teori \& Praktik). Jakarta: Bumi Aksara. 2015.

Hendriansyah. Pengelolaan harta wakaf pada perguruan Islam Al-Syukro Universal Ciputat Tangerang Selatan. Konsentrsi Manajemen Zakat dan Wakaf (ZISWAF). Program Studi Muamalat (Ekonomi Islam). Fakultas Syariah dan Hukum, Universitas Islam 
Negeri (UIN) Syarif Hidayatullah Jakarta. 1436 H/2015 M.

Kartono, Kartini. Penghantar metodologi Riset Sosial. Bandung: Mandar maju. 1990.

Masruchin. Wakaf Produktif dan Kemandirian Pesantren (Studi tentang Pengelolaan wakaf Produktif di Pondok Modern Darussalam Gontor Ponorogo). Tesis Program Studi Ilmu Ekonomi Shari'ah Fakultas Syariah Universitas Islam Negeri Sunan Ampel. 2014.

Nawawi, Ismail. Fiqh Muamalah Klasik dan Kontemporer. Bogor: Ghalia Indonesia, 2012.

S. Margono. Metodologi Penelitian Pendidikan. Jakarta: Rineka Cipta. 2003.
Shomad, Abd. Hukum Islam: Penormaan Prinsip Syariah dalam Hukum Indonesia. Jakarta: Kencana Prenada Media Group. 2012.

Soekamto, Soerjono. Pengantar Penelitian Hukum. Jakarta: UI Press., 1998.

Undang-undang No. 41 tahun 2004 Tentang Wakaf.

Yusuf, Andi "Pendayagunaan Tanah Wakaf pada Yayasan Uswatun Hasanah di Desa Lempuyang Kecamatan Anjatan Kabupaten Indramayu (tinjauan hukum Islam dan PP No. 28 Tahun 1977)" Skripsi diterbitkan, Program Studi Al- Ahwal Al-Syakhsiyyah Jurusan Syari'ah STAIN Cirebon. 2003. 